\title{
Role of Porcine Base Anticoagulant during Pregnancy and Puerperium as Prophylaxis Treatment in Venous Thromboembolism (VTE): Shariah Views and Perspectives
}

\author{
Irwan Mohd Subri, Zizi Azlinda Mohd Yusof, Nur Zaireena Zainal, Azman Ab Rahman, Mohd \\ Nasir Abdul Majid, Nadeeya 'Ayn Umaisara Mohamad Nor
}

\begin{abstract}
Physiological changes in pregnancy makes the pregnancy a hypercoagulable state. Recent Malaysian maternal mortality enquiry in 2016-2017 statistic revealed that the principal cause of maternal death is caused by venous thromboembolism (VTE) particularly pulmonary Embolism (PE). Low Molecular Weight Heparin (LMWH) is the treatment of choice in pregnancy due to its efficacy, effectiveness and safety profile which is superior then other anticoagulants. Unfortunately, LMWH is porcine base anticoagulant which creates a huge hesitancy and dilemma amongst Muslim medical practitioners. Perplexity especially in preventive treatment as the national fatwa issued permissible usage only in life threatening necessity. The objective of this study is to evaluate the principals in shariah towards mothers at risk of VTE during pregnancy and puerperium whom will be prescribed porcine base anticoagulant as prophylaxis. Utilizing textual content analysis in this qualitative research, the outcome will clarify the feasibility by al-zikr or ahl al-khibrah in porcine based medication as VTE prophylaxis treatment. This study aimed to purpose a new perspective in delineating the dilemma among Muslim practitioner.
\end{abstract}

Index Terms: Anticoagulant, prophylaxis, Low Molecular Weight Heparin (LMWH), Muslim, Venous Thromboembolism (VTE).

\section{INTRODUCTION}

Islam encourages every Muslim to appreciate life and moderation in everything to achieve good health; to seek remedy and cure for ailments. Prevention is always better than cure. Based on the principle of maqasid al-shariah, the concept of sadd al-dzara' $i$ which is the fiqh methodological in preventing the unfavourable outcome [1] shall be applied to prevent life threatening condition to occur. Globally, technology advancement in medical and pharmaceutical field has rapidly revolutionised the preventive medicine and minimizing the life threatening disease to occur [2].

Revised Version Manuscript Received on September 16, 2019.

Irwan Mohd Subri, Faculty of Shariah and Laws, Universiti Sains Islam Malaysia, Nilai, Negeri Sembilan, Malaysia.

Zizi Azlinda Mohd Yusof, Faculty of Shariah and Laws, Universiti Sains Islam Malaysia, Nilai, Negeri Sembilan, Malaysia.

Nur Zaireena Zainal, Faculty of Medicine and Health Sciences, Universiti Sains Islam Malaysia, Nilai, Negeri Sembilan, Malaysia.

Azman Ab Rahman, Faculty of Shariah and Laws, UniversitI Sains Islam Malaysia, Nilai, Negeri Sembilan, Malaysia.

Mohd Nasir Abdul Majid, Faculty of Shariah and Laws, Universiti Sains Islam Malaysia, Nilai, Negeri Sembilan, Malaysia.

Nadeeya 'Ayn Umaisara Mohamad Nor, Faculty of Medicine and Health sciences, Universiti Sains Islam Malaysia, Nilai, Negeri Sembilan, Malaysia.
Pharmaceutically develop medication and human bio-prosthetic components are inevitable from porcine source. This is because the phylogenetic and proteins are almost similar and compatible to human body system than mice [3]. Thus, it is use by many biomedical researchers to help in developing new effective medications for human.

However, the prohibition of using lahm al-khinzir is well-known in Islamic teaching which is clearly stated in Al-Quran (Surah al-An'am: 145 and Surah al-Maidah 5:3). Although Al-Quran mentioned the word of lahm which means flesh of the porcine, it was clarified that it includes the lard or any other porcine base products. [4], [5]. Following this, the consensus between Muslim jurist (Ijma') had agreed that Muslims are prohibited from eating the flesh of pork and its derivatives as it is a sin and impiety to do so [6]. Thus, the Malaysian National Fatwa Council (MNFC) has progressively issued upon any porcine related product including medicines as equivalently prohibited. Therefore, it is crucial to comprehend the essential teaching of halal and haram in porcine related medicinal products usage among Muslims as the majority population in Malaysia.

Concerned with the emerging porcine based medicinal substances, fatwa on porcine based low molecular weight heparin (LMWH) anticoagulant, had been issued 10 years ago, in 2009. Although LMWH anticoagulant is known to be effective as treatment for venous thromboembolism (VTE), it was prohibited due to its porcine's origin. This is because there was a new non-porcine LMWH available, which offers a halal alternative and synthetically produced called Fondaporinux. The latter claimed to have similar functions and effects as porcine based LMWH [7].

Fondaporinux was relatively new during the Fatwa statement issued in 2009. Thus, there was limited data upon the usage in pregnancy and post-delivery. However more recent clinical evidences showed that Fondaporinux safety profile upon pregnant and puerperium women whom at risk of getting VTE are rather limited and less recommended [8].

The emerging evidences on safety profile of Fundaporinux which is less favourable as compare to the porcine base LMWH shows that the statement by MNFC require extensive and rigorous reviews. Further discussion between Islamic

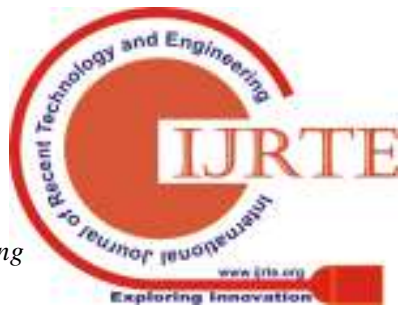


jurists with more recent evidences to refine the statement upon the permissibility of porcine based LMWH usage as preventive medicine among pregnant women and during puerperium. Not to mention that due to its safety profile and proven efficacy, the porcine based LMWH are widely recommended throughout the globe and incorporated into various guidelines. This includes the local guideline for treatment of VTE, yet the Malaysia ministry of health whom produces the local guideline seems to have separated view upon the MNFC causing confusion and uneasiness between practitioner and the patient themselves.

The pregnancy is even more complicated because of three reasons; first, the treatment sought due to VTE to ascertain healthy recovery for both mothers and fetus. Second, physiological changes in pregnancy and puerperium makes the efficacy of certain medications less effective. Third, limited established high-impact research during pregnancy.

With the above preliminary, the objective of this study is to evaluate the principal in shariah towards mothers at risk to develop VTE during pregnancy and puerperium whom will be prescribed porcine base anticoagulant as prophylaxis treatment. The research question is to evaluate the different perspective and concept in shariah principles and to determine the permissibility of porcine base LMWH usage in prophylaxtic treatment of VTE during pregnancy and puerperium.

\section{METHODOLOGY}

This is a qualitative research where the textual content from Classical and contemporary Fiqh books were analysed upon the issue of preventive medicine specifically on porcine base thromboprophylaxis LMWH. This is because VTE incidence being the principal cause of maternal mortality and it is the recommended treatment based on the Clinical Practical Guideline [9] provided by Ministry of Health (MOH).

\section{LITERATURE REVIEW}

Literatures concerning on the prevention of diseases morbidity and mortality related to VTE from Islamic perspective, guideline provided by $\mathrm{MOH}$ using clinical practical guideline (CPG) in Malaysia, and the qaedah fiqhiyyah in the prevention of VTE incidents.

\section{A. Prevention in Islam}

The current modernization and advancement in medical development it still endures Islamic concept on prevention is better than cure (al-wiqayah khairu min al-'ilaj) [10]. Islam encourages every Muslim to take a good care of health and it reflects in many of the practices including self-hygiene, eating in moderation and fasting. All these are meant to achieve good health by prevention of ailments. Thus, the role of prophylaxis in Islam is very important hence to prevent further complications in pregnancy following incidences of which can be fatal.

\section{B. Definition of prevention}

The medical practitioners prefers the term prophylaxis which means prevention in discussing the management to avoid further complications or side effect following the disease or treatment for VTE. Prophylaxis origins from the
English word 'pro' which means before and later added with the word 'phulaxis' from a Greek word which means the act of guarding. These two words later were combined and named under modern Latin as prophylaxis. Therefore, thromboprophylaxis in this literature denotes to "Any preventive measure or medication that reduces the likelihood of the formation of blood clots" [12].

In another hand, prevention in Arabic in known as al-wiqayah. Ibn Manzur in his book, Lisan al-Arab stated that al-wiqayah means "Allah prevent him with prevention" [13], it also said, "I am prevented from something from destruction". Al-Quran mentioned the word al-wiqayah from surah Al-Insan verse 11:

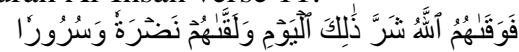

"So Allah will protect them from the evil of that Day and give them radiance and happiness"

Al-wiqayah also interpreted as knowledge of prevention from diseases and to strengthen the wellbeing individually or in society [14]. The word al-tibb associated with al-wiqai' (al-tibb al-wiqai'), it denotes to a more comprehensive meaning; where a knowledge in preservation either individually or in a bigger society to be in a good health, which can be achieve through two different ways. The first, prevention from the diseases to occur and to stop it once diagnosed. Secondly, preservation of individual health by improving the way of life's in a person and prohibit from factors which can contribute to the diseases or illness to happen" [15].

In conclusion, al-wiqayah can be interpreted as prevention from disease's development by eliminating all the risk factors either external or internally. Internal factors are any related causes due to the patient own genetic makeup, dietary and lifestyle. Whilst, external factors are defined by all the possible factors which is non-dependent to the person for example the medications given, surgical techniques and skilled health care providers. In this research, the risk factors of developing VTE among pregnant and post-partum women are observed carefully including the prophylaxis treatment with porcine base LMWH as required according to the Malaysian CPG.

\section{The fundamental understanding regarding al-wiqayah} in Islam

Preservation of health and avoidance from illness are the fundamental issues in medical treatment. This is further supported as it was long mentioned in al-Quran related to wiqayah including Al-Tahrim: 6, Al-Hasyr: 9, Al-Taghabun: 16, Ghafir: 9, Al-Baqarah: 201, Al-Nahl: 81, Al-Ra'd: 37, Al-Insan: 11, Ghafir: 45, Al-Baqarah: 195, Al-isra': 32, Al-Mukminun: 5-7.

The verse in surah Al-Baqarah 2:195 directly encourage and emphasize Muslims not to throw ourselves into the destruction. Similarly, in surah al-Isra' verse 32 elaborating about the prohibition on prostitution or any similar behaviour. The verse stressed on the word la taqarabu, which means do not ever get closer to any behaviour which lead further to prostitution. Then, Surah Al-Mu'minun verse 5-7 also advocate to keep yourselves safe from fahishah or ill

Published By: 
deeds. Those nusus or known as the detail evidences from Al-Quran implicitly commands Muslims to prevent themselves from destructions including from ill manners which leads to self-destructing diseases.

From the verses mentioned, it is concluded that the term of al-wiqayah navigates Muslims to protect and prevent themselves from any risk factors including ill behaviors which can lead to any ailments.

D. Al-Wiqayah in Islamic medical practices in the beginning of Islam

Islam advocates Muslim to seek the benefit of healthy life. The scopes of al-wiqayah in Medical Islamic practices during the time of Prophet (PBUH) and his companions (May Allah be pleased with them) can be classified into two scopes:

Prohibition to use intoxicants ingredient in food, beverage or medicinal substances

Food and beverages are among the most crucial matters discussed in great depth among the Muslim scholars (ulama'). It is directly addressed either in Al-Quran or Al-Hadith. The importance of foods' sources in Muslim dietary are paramount in being a good Muslim as it the basis for human development either physically, mentally and spiritually which later reflects in behavior or practices. Haram food which contained impure ingredient (al-khabaith) is totally prohibited as mentioned in Al-Quran:

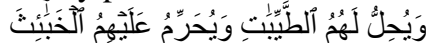

"and makes lawful for them the good things and prohibits for them the evil" (Surah Al- 'Araf: 157)

According to Ali bin Abi Talhah from Ibnu Abbas, al-khabaith interpreted as flesh of pork, interest and all types of forbidden food category while few Muslim scholars perceived as any substances that are consider impure by which can harm to body and religion [16]. Al-Baydawi in another hand concluded that the word al-khabaith as flesh of pork and blood in terms of food and interpreted as interest and bribery in the context of non-food related [17].

In the past, the source of halal and non halal substances in food beverages or medicinal product were easily identified. Al-Wiqayah in food and beverage is transparent as compare to any substances used in medicine. Furthermore, Muslim scholars do emphasize on taking a good care of dietary and food as it will steer away many ailments and need for medicine. It is clearly stated in the verses, that the scope of prevention in Islam in food, beverages and medicine are required to avoid from taking al-khabaith substances and consume the medicine or al-toyyibat

Preventive measures using Separation Method (Qaedah al- 'azl)

Few narrated hadiths elaborate on separation method has been implemented during the time of Prophet (PBUH) and his companions (May Allah be pleased with them) either in the houses or hospitals. One of the examples was the prevention steps in transmission of contagious diseases from the sick to the healthy person [18].

The Muslim whom was an owner of the sick camel was reminded not to give drink at the same place where other healthy camel feed or drink. It was meant to protect the disease from being transmitted around. Islam prohibits actions that might increase the rate of contagious diseases among the individual and society as a whole.

This can be seen when the contagious disease carriers are advised to be separated from healthy and fit one, for instance Cholera and Influenza infection. A good example Cholera infection which happens due to poor sanitation and hygiene, it causes severe diarrhea and vomiting. It is very contagious, able to transmit quickly and may lead to life threatening sequele and often fatalities. Hence, the command is to flee away from diseased area in an outbreak if not infected, but to stay if already infected or in the area. So that, it is not contagious to others and prevent spread of the disease. Islam advocates upon Muslims to prevent themselves from seeking any illness.

Al-Wiqayah in medical Islamic practices in the modern era

Over the last few decades, the medicinal development rapidly changes human life including al-wiqayah in medical practices. There is no conflict input between al-wiqayah from diseases. Preventive medicine are more accepted due to the advancing facilities and expertise. The availability of thromboprophylaxis treatment against VTE during pregnancy and puerperium creates issue as the treatment is best with porcine based LMWH Prophylaxis (Prevention) from VTE during pregnancy and puerperium.

In this research, pregnancy and puerperium will be the main issue and filling the gap which is aimed to explore what are the shariah principle which is relevant to prevent VTE during pregnancy and puerperium with porcine base anticoagulant.

\section{Definition of VTE}

Venous thromboembolism is "a blood clot that forms in a vein and travels to another location. Typically, the clot in a deep venous thrombosis that becomes a pulmonary embolism; it often has serious health consequences" [19].

VTE is never been a minor public health; instead it is a serious killer disease globally especially in developed countries. VTE commonly manifested into two types, pulmonary embolism (PE) and deep vein thrombosis (DVT).

\section{VTE during pregnancy and puerperium}

Obstetric VTE may manifest as deep venous thrombosis (DVT) and Pulmonary embolism (PE) which are the principal cause of maternal mortality in Malaysia and similarly in most developed countries. VTE occurs with prevalence one in 1,600 and it is responsible for maternal mortality approximately $9 \%$ [20].

Pregnancy itself is the potential risk for VTE with $4-10$ times compared to non-pregnant state while puerperium poses a higher risk than pregnancy state with 15 to 35 folds compared to age-matched non-pregnant women [21]. The actual risk of death from obstetric VTE specifically Pulmonary Embolism (PE) begins at first week postpartum is approximately 1.1 out of 100,000 [22].

VTE in pregnancy is postulated due to the components of Virchow's triad [23] which include, hypercoagulability, venous stasis and endothelial vascular damage, these factors occur during pregnancy and continue throughout the puerperium period. 
Hypercoagulability state is normal for pregnant women due to altered thrombotic and fibrinolytic system leading to hypercoagulation state which is a physiological adaptation in pregnancy. Venous stasis happens due to pressure from the increasing size of uterus and fetus grow as the gestation advances further compresses on the iliac veins and vena cava [24]. While vascular damages occur in pelvic venous circulations following the caesarean surgery and deemed as the main contributing factors to vascular endothelial injury.

Although Vichow's triad presents in almost every pregnant women, there are numerous research depicts on other contributing risk factors which further contribute to the formation of blood clot including increased maternal age, obesity, cesarean delivery, immobilization due to admission or comorbidities, dehydration secondary to hyperemesis, and a history of thrombosis or thrombophilia [25].

\section{Prevention and treatment of VTE}

In many of the obstetric related VTE guidelines, the treatment is divided into two type namely a) Prevention or prophylaxis treatment; and b) Therapeutic treatment. All pregnant women are highly recommended to undergo a detail assessment of risk factors for VTE in early pregnancy and subsequently reviewed again after delivery.

These women will be stratified into groups according to their risk factors: 1) High risk with risk factors such as single previous VTE, or 2) Intermediate Risk when the women have any one of the listed risk factors (table 1) which includes single previous VTE with no family history presence of medical comorbidities such as, malignancies, Systemic Lupus Erythematous, major Thalassemia, Sickle cell disease, nephrotic syndrome, inflammatory conditions and intravenous drug user. 3) Low risk group includes age more than 35 years, obesity with body mass index (BMI) over $30 \mathrm{~kg} / \mathrm{m}^{2}$, parity three or more, unhealthy lifestyle such as smoking, dehydration, immobility following travel in air plane, multiple pregnancy, assisted reproductive treatment, pre-eclampsia and gross varicose veins. Each of these risk factors are calculated and categorized following the prophylaxis level and given a VTE score. The calculated score will determine the thromboprophylaxis requirement dosing and duration with LMWH to prevent incidence of VTE.

$\mathrm{MOH}$ as documented in the local guideline as well as in Manual Training of Prevention and Treatment of VTE during pregnancy and Puerperium has produced as in following table.
Table 1: Management of prevention of VTE according to CPG published by MOH [26] ${ }^{1}$

\begin{tabular}{|l|l|}
\hline Risk Stratification & Prevention \\
\hline $\begin{array}{l}\text { High risk (score 4 and } \\
\text { above) }\end{array}$ & $\begin{array}{l}\text { Require antenatal } \\
\text { prophylaxis with LMWH } \\
\text { either Enoxaparin 1mg/kg } \\
\text { or Tinzaparin 4500units } \\
\text { daily (if BMI under 90kg, } \\
\text { to dose at 75 units/kg } \\
\text { daily) }\end{array}$ \\
\hline $\begin{array}{l}\text { Intermediate/moderate risk } \\
\text { (score 3) }\end{array}$ & $\begin{array}{l}\text { Consider antenatal } \\
\text { prophylaxis with LMWH } \\
\text { either Enoxaparin 1mg/kg } \\
\text { or Tinzaparin 4500units } \\
\text { daily (if BMI under 90kg, } \\
\text { to dose at 75 units/kg } \\
\text { daily) }\end{array}$ \\
\hline Low risk (score 1 and 2) & $\begin{array}{l}\text { Nonpharmacological } \\
\text { thromboprophylaxis } \\
\text { Mobilization and avoid } \\
\text { dehydration }\end{array}$ \\
\hline
\end{tabular}

Postnatal women should be assessed after delivery and stratified into these risk groups based on their risk factors and shall offered thromboprophylaxis with LMWH whereever appropriate. Any women suspected to have symptoms suggestive of VTE also should be assessed and scored with a proper documentation. The risk factors for postnatal are similar to the antenatal assessment, however the management in order to prevent incidence of VTE after delivery are emphasized by duration of treatment according to the risk factors.

Table 2: Management of prevention of VTE according to CPG published by MOH [27] ${ }^{2}$

\begin{tabular}{|l|l|}
\hline Risk Stratification & Prevention \\
\hline $\begin{array}{l}\text { High risk (score 4 and } \\
\text { above) }\end{array}$ & $\begin{array}{l}\text { At least 6 weeks } \\
\text { postnatal prophylactic } \\
\text { LMWH }\end{array}$ \\
\hline $\begin{array}{l}\text { Intermediate/moderate } \\
\text { risk (score 3) }\end{array}$ & $\begin{array}{l}\text { At least 7 days postnatal } \\
\text { prophylactic LMWH } \\
\text { If persisting or more than } \\
\text { 3 risk factors, consider } \\
\text { extending } \\
\text { thromboprophylaxis with } \\
\text { LWMH }\end{array}$ \\
\hline Low risk (score 1 and 2) & $\begin{array}{l}\text { Nonpharmacological } \\
\text { thromboprophylaxis } \\
\text { Mobilization and avoid } \\
\text { dehydration }\end{array}$ \\
\hline
\end{tabular}

\section{RESULTS AND ANALYSIS}

A.The necessity of ahl al-zikr (ahl al-khibrah) in thromboprophylaxis for obstetric related VTE

Preventions from any VTE incidences or complications should be seriously taken into account. The prevention includes thromboprophylaxis treatment with LMWH is highly recommended to avoid from developing into VTE during pregnancy and puerperium. 
In Islam, the opinion from the experienced and wise scholar (ahli khibrah) is reliable to justify a reasonable statement upon any fatwa issued. It is mentioned in Al-Quran specifically in surah Al-Nahl 16: 43

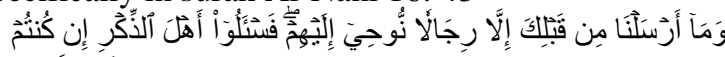

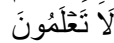

"And We sent not before you except men to whom We revealed [Our message]. So, ask the people of the message if you do not know".

" in that Holy verse translated as "People of the message" literally.

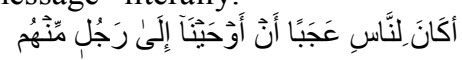

"Have the people been amazed that We revealed [revelation] to a man from among them" (Yunus 10:2) and another verse mentioned in Surah Al-Nahl 16:43:

This verse explains that the previous ahl al-kitab is the member of the books message). It was also quoted that Mujahid said from Ibn Abbas he said; "The meaning of ahl al-zikr is ahl-kitab" ahl-zikr as the members of the books [28], [29]

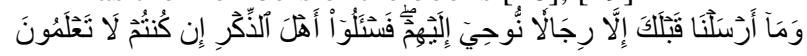

"And We sent not before you, [O Muhammad], except men to whom We revealed [the message], so ask the people of the message if you do not know".

The word of ahl al-zikr in this verse is referred to previous ahl al-kitab, but interpreted based on the method "al-"ibrah bi umum al-lafz la bi khususi al-sabab", Ibn "Atiyyah mentioned that ahl al-zikr denoted to any expertise whom are knowledgeable in their field. Thus, ahl al-zikr here are also referred as ahl al-ikhtisas in his field or specialty which means the expertise or the specialist in their field.

According to the usul fiqh reference [30], in the provision by a mufti, any fatwa should not be issued unless refer and discuss with ahl al-khibrah in the various related area in order to know in detail about the subject matter such as the issues of medical and economy.

Al-Qaradawi elaborated succinctly that a mufti shall inquiries and obtains all the data needed to ahl al-zikr or khabir to impose a fatwa according to few Surah al-Quran such as Surah al-Nahl verse 43:

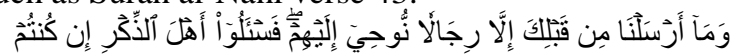

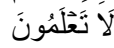

Meaning: "And We sent not before you except men to whom We revealed [Our message]. So, ask the people of the message if you do not know".

Surah Fatir verse 14 mentioned:

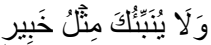

Meaning: "And none can inform you like [one] acquainted [with all matters]".

Surah al-Nisa' verse 83:

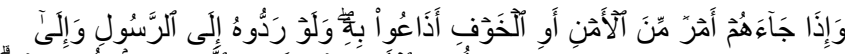

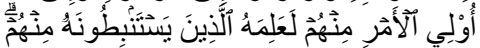

Meaning: "And when there comes to them information about [public] security or fear, they spread it around. But if they had referred it back to the Messenger or to those of authority among them, then the ones who [can] draw correct conclusions from it would have known about it".

Therefore, the term al-khabir is synonym to ahl al-zikr and it is used interchangeably. Thus, referring to the matter discussed regarding the management of VTE, the ministry of
Similarly in surah Al-Anbiya' verse; which referred

health consists by a team of experienced and knowledgeable medical consultants whom studied and produce a guideline related to VTE management and its prevention during pregnancy and puerperium.

B. Qaedah fiqhiyyah in prevention of VTE

during pregnancy and puerperium with porcine base anticoagulant (lmwh)

In Malaysia, the application of qawaed fiqhiyyah is declared as the main reference for shariah principle in determining the permissibility of porcine base anticoagulant LMWH such as (Clexane) usage in prevention of VTE during pregnancy and puerperium. According to Islamic ruling there are two method in determining a specific decree, 1) the normative religious ruling sanctioned from the very beginning ('azimah) 2) the concession or known as rukhsah. The rukhsah [31] is applicable upon preserving maslahah or values of life (hifzu al-nafs). In Islam, there are five main qawaed fiqhiyyah in solving many problematic issues such as:

i. Al-umur bimaqasidiha (acts are valued in accordance with the underlying intention)

ii. Al-Yaqin la yazulu bi al-syak (certainty is not overruled by doubt)

iii. Al-Masyaqqah tajlibu al-taysir (hardship begets facility) iv. Al-Darar la yuzal (harm must be eliminated)

v. Al-'Adah Muhakkamah (custom is the basis of judgement)

This research will imply this prevention of VTE case with the qaedah fiqhiyyah namely al-masyaqqah tajlibu al-taysir which means hardship begets facility. The original source of this qaedah fiqhiyyah derived from Surah al-Kahfi 8:73.

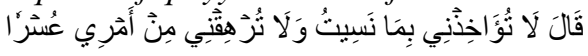

Meaning: "[Moses] said, "Do not blame me for what I forgot and do not cover me in my matter with difficulty".

Based on that evidences and proof from Al-Quran, it shows that Islam embraces the concept of helping others in moderation to its followers. The main principle is to identify the hardship (masyaqqah) and thus the difficulties in implementation will later become the main cause (sabab) of rukhsah which is the exception of Islamic ruling in special condition. Referring to the issue of thromboprophylaxis treatment using porcine based LMWH during pregnancy and puerperium, it has become the issues or maslahah of life, and it is succinctly related to critical and life threatening (haraj) matter. In critical condition or life threatening matters, the shara' advocates permissibility and special exemption to use porcine base medicine as it is the best option to eliminate the critical condition and is consider a rukhsah, as mentioned in Surah Al-Fath 48: 17:

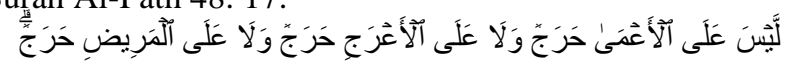

Meaning: "There is not upon the blind any guilt or upon the lame any guilt or upon the ill any guilt [for remaining behind]. away -

Therefore, any define hardship, critical conditions, difficulties, or burden conditions do have a special clause for rukhsah which is applicable under the the qaedah fiqhiyyah al-masyaqqah tajlibu al-taysir. Under that five main qawaed 
fiqhiyyah, there are other qawaed fiqhiyyah methods which essentially expressed that Islam facilitates Muslims to live within the rulings with special circumstances allow flexibility

i. Idza daqa al-amru, ittasa'a

ii. Idza ittasa al-amru, daqa

iii. Al-Darurat tubihu al-mahzurat

iv. Al-Darurat tuqaddar biqadariha

v. Ma jaza li 'uzrin batala bizawalihi

vi. Al-Hajah tunazzal manzilah darurah

vii. Al-Idtirar la yubtilu haq al-ghayr

viii. Al-hukmu yatba'u al-maslahat al-rajihah

ix. Al-hukmu yaduru mazal illatihi

x. Yunazzalu al-majhul manzilat al-ma'dum

Yet among many methods of flexibility in providing rukhsah throughout a Muslim life, it can only be determined by a team of expertise in the field including the wise and knowledgeable Muslim scholars.

\section{DISCUSSION}

The eligibility of prevention of VTE during pregnancy and puerperium with using porcine base anticoagulant, LMWH such as Clexane is best interpreted and define under the qaedah fiqhiyyah al-darar yuzal or al-darurat tubih al-mahzurat. In fact, in the case of prevention (prophylaxis) of VTE during pregnancy and puerperium, it should be prioritized (min bab al-aula) because of the potential harm for both fetal and maternal complications as mentioned by [32]. Moreover, the paucity of relevant high-quality research to include pregnant or puerperium women as experimental sample is considered unethical to be carried out. Thus, the evidences are based from reviews of pool of statistic data, comparative studies and observational researches globally. Sufficient information obtained as many guidelines have recommended the superiority in efficacy, and safety profile of porcine base LMWH anticoagulant such as Clexane in prevention of VTE for pregnant women and puerperium. Therefore, a degree justification on flexibility or rukhsah among Muslims should be considered.

The current available CPG and training manuals in prevention of VTE during pregnancy and puerperium which are considered as ahl al-zikr or ahl al-khibrah, has highly recommended for the high risk mother (VTE score 4 and above) including the moderate risk patients (VTE score 3 ) to utilize the prophylactic treatment LMWH such as Clexane even though it is porcine in origin. There is an urge to use the recommended medication as it has been proven to reduce the incidence, reduce risk of morbidity and mortality and better safety profile. The justification for rukhsah based on the qaedah fiqhiyyah "need is ranked as necessity" or in Arabic "al-hajah tunazzal manzilah darurah".

This is further supported by few qawaed usuliyyah related to al-hajah which permits forbidden things (al-mahzurat) such as "need permits forbidden, in another hand it means; prohibited is allowed if there is a need which is properly define" which later translated into Arabic as "al-hajah tubihu al-mahzur, al-haram yubahu lil hajah" [33]. The above mentioned qaedah usuliyyah is similar to the narrated hadith of Abu Balta'ah, Ubaydullah bin Rafi' whom reported: I heard Ali (Allah be pleased with him), Allah's Messenger (PBUH) sent me, Zubayr and Miqdad saying: Go to the whenever there is a need, for instance:

garden of Khah (Raudhah Khah) (it is a place between Mecca and Medinaat a distance twelve miles from Medina) and there you will find a woman is riding a camel. She would be in profession of a letter, which you must get from her. So we rushed on horses and we met that woman, we asked her to deliver us that letter to us. She said, 'there is no letter with me'. We said, 'either bring out that letter or we would take off your cover. She brought out that letter from (the plaited hair of) her head" (Sahih Muslim). This hadith shows to us that it is permissible to see woman's private part of body (aurah) in the darurah situation. The above discussion, it is observed that the prevention of VTE during pregnancy and puerperium is classified in bab al-aula as the highest priority due to maslahah or issues of lives in which to prevent a devastating complication to the pregnant mother and the baby.

There are two hadith directly related to permissible to use forbidden substance for medical treatment for his hygienic need as in the case of mangy man in the time of Prophet (PBUH). It was narrated that Anas (May Allah be pleased with him) said; the Messenger of Allah (PBUH) has allowed Abdul Rahman bin 'Auf and Zubayr bin Al-Awwam to wear silk garments because of skin rash they had (Hadth Bukhari and Muslim). The second hadith shows to us about the permissibility of using muharram in medicine. It is reported that the nose of 'Arfaja bin As'ad was severed on the day of Kilaab, so he obtained a silver artificial nose, but it produced an offensive order. As a result, the Prophet (PBUH) ordered him to obtain a gold artificial nose as replacement [34].

It is known that the wearing silk cloth to ease the itchy mangy skin and as well as artificial nose made of gold are not related to death. While these pregnant women are known with current evidences are already at increased risk to develop VTE which can be fatal. Thus, it is very crucial to prioritize these women with VTE score 3 and above to use the porcine base LMWH anticoagulant as prophylactic treatment (min bab al-aula).

Although the literatures show that VTE incidences during pregnancy and puerperium are low, but the outcome ended with mortality and increasing in trend [35]. The obstetric VTE mortality accounts up to $9.2 \%$ of deaths related VTE or 1.5 out of 100,000 live births in the United States. In Malaysia, most tertiary hospital has LMWH anticoagulant used antenatal and postnatally. Among the states, Sarawak had implemented intensive VTE in obstetric prevention programme emphasizing the usage of LMWH anticoagulant starting from VTE score 3 and above including VTE score 2 if cesarean section delivery; they do have documented evidence of remarkable reduction of VTE related maternal mortality. The awareness and early intervention including prophylactic treatment should be emphasize as the risk factors such as cesarean section and obesity are increasing at alarming rate globally. Hence, there is a tenacious need to emphasize on the usage of LMWH anticoagulant, although the best option is the medicine extracted from porcine intestinal mucosa layer it shall be ranked as necessity. This is further supported by [36] in the qaedah usuliyyah stated that "Need is a cause of concession" or in Arabic "al-hajah sabab 
al-rukhsah". Therefore, the usage of porcine based LMWH is applicable in this method as the cause or sabab as it is needed as prophylactic treatment and to prevent a greater complication.

Meanwhile, the CPG recommends to encourage mobilization and avoid dehydration for low risk group in preventing VTE incidence during pregnancy and puerperium These low risk (VTE score 1 and 2) group of women the suitable prevention method is under the qaedah usuliyyah in hajah matters as "every flexibility granted to the need,is permissible; yet, it does not applicable to all condition which has not happen or any calling to do so" (Kullu rukhsah ubihat lil hajah lam tustabah qabla wujudiha). Indeed, the low risk mothers whom do not have any symptom of VTE do not require any pharmacological treatment using anticoagulant such as LMWH as stated in the guidelines.

\section{CONCLUSION}

In a nutshell, the principles of tenacious need to justify the usage of porcine base LMWH anticoagulant for high risk group of women can be expressed as al-hajah tunazzal manzilah darurah. The local clinical guidelines have similar recommendations with the other guidelines used globally to prophylactically prevent risk of developing VTE during pregnancy and puerperium. Therefore, all pregnant women are required to undergo risk assessment using scoring system as recommended in the guideline. The VTE risk scoring system will further helps to determine the justification of qaedah fiqhiyyah upon the prophylactic treatment. As a summary, prevention of VTE with using porcine base anticoagulant such as LMWH or Clexane is permissible based on the justification on a firm need as preventive stage in Malaysia. This research is important because it helps to clarify the confusion and dilemma between medical Muslim practitioner and patients. Thus, an urge to revisit the fatwa on the LMWH (Clexane) upon its usage as preventive medicine among pregnant Muslim women whom are at increased risk to develop VTE incidence.

\section{ACKNOWLEDGMENT}

The study is conducted with cooperation between World Fatwa Management and Research Institute, Universiti Sains Islam Malaysia, under the Sanofi Aventis industrial grants.

\section{REFERENCES}

1. M. H. Borhani, Sad al-Dzara'i' fi al-Shariah al-Islamiyyah. Damsyiq: Dar al-Fikr, 1995.

2. ISTH Steering Committee for World Thrombosis Day, "Thrombosis: A major contributor to the global disease burden 2014," J Thromb Haemost, 12, 2014, pp. 1580-1590.

3. E. M. Walters, K. D. Wells, E. C. Bryda, S. Schommer, and R. S. Prather, "Swine models, genomic tools and services to enhance our understanding of human health and diseases," Lab Animal, 46(4), 2017, pp. 167-172.

4. Zamakhsyari, al-Kasysyaf. Egypt: Maktabah al-'Abikan, 1998.

5. Qurtubi, al-Jami` li Ahkam al-Quran. Lebanon: Mu'assasah al-Risalah, 2006.

6. N. A. Fadzlillah, Y. C. Man, M. A. Jamaludin, S. A. Rahman, and H. A. Al-Kahtani, "Halal food issues from Islamic and modern science perspectives," 2nd
International Conference on Humanities, Historical and Social Sciences IPEDR, 2011, pp. 159-163.

7. JAKIM, Kompilasi pandangan hukum Muzakarah Jawatankuasa Fatwa Majlis Kebangsaan bagi Hal Ehwal Ugama Islam Malaysia. Putrajaya: JAKIM, 2015.

8. A. E. Fogerty, "Challenges of anticoagulant therapy in pregnancy," Curr Treat Options Cardio Med, 19(76), 2017, pp. 1-13.

9. Ministry of Health (MOH), Clinical Practical Guidelies Prevention and Treatment of Venous Thromboembolism. Putrajaya: MOH, 2013.

10. A. R. Gatrad and A. Sheikh, "Medical ethics and Islam: Principles and practices," Arch Dis Child, 84, 2011, pp. 72-75.

11. The Free Dictionary, Medical dictionary. Available: http://www.medical-dictionary.thefreedictionary.com

12. M. Mukram, Lisan Al-Arab. Beirut: Dar Sadir, nd.

13. A. Belali, al-wiqayah al-sihhiyyah fi al-sunnah al-Nabawiyyah dirasah maudu'iyyah. Master thesis, University of Al-Algeria, 2010.

14. M. H. al-Hawli, al-tib al-waqa'i fi al-Islam. Available: http://site.iugaza.edu.ps/mholiy/files.

15. I. U. Kathir, Tafsir al-quran al-azim. Riyadh: Dar toyyibah li al-nasyr wa al-tawzi', 1997.

16. A. U. Baydhawi, Anwar al-tanzil wa asrar al-takwil. Beirut: Dar Ihya' Turath al-arabiy, nd.

17. M. A. al-Qudumi, "Al-sihhah al-waqa'I fi al-Islam," Majallah Jami'ah al-quds al-mafruhah lil abhath wad dirasat, 26(1), 2012, pp. 185-208.

18. The Free Dictionary, Medical dictionary. Available: http://www.medical-dictionary.thefreedictionary.com.

19. I. Greer and B. J. Hunt, "Low molecular weight heparin in pregnancy: Current issues," British Journal of Haematology, 128, 2015, pp. 593-601.

20. M. S. Gomes, M. Guimaraes, and N. Motenegro, "Thrombolysis in pregnancy: A literature review," Journal of Maternal-Fetal and Neonatal Medicine, 32(14), 2018, pp. 2418-2428.

21. A. P. H. Burgess and S. L. Clark, "Opportunities for hospitals, hospital systems and leadership to improve VTE prophylaxis," Seminar in Perinatology, 2019, pp. $1-4$.

22. G. Gray, "Thromboembolic disorders in obstetrics," Best Practice and Research Clinical Obstetrics and Gynaecology, 26, 2012, pp. 53-64.

23. K. Meng, X. Hu, X. Peng, and Z. Zhang, "Incidence of venous thromboembolism during pregnancy and the puerperium: A systematic review and meta-analysis," Journal of Maternal-Fetal and Neonatal Medicine, 28(3), 2015, pp. 245-253.

24. N. Abbasi, J. Balayla, D. P. Laporta, A. Kezouh, and H. A. Abeinham, "Trends, risk factors and mortality among women with venous thromboembolism during labour and delivery: A population-based study of 8 million births," Arch Gynecol Obstet, 289(2), 2013, pp. 275-284.

25. MOH, Clinical Practical Guidelies Prevention and Treatment of Venous Thromboembolism. Putrajaya: MOH, 2013.

26. $\mathrm{MOH}$, Clinical Practical Guidelies Prevention and Treatment of Venous Thromboembolism. Putrajaya: MOH, 2013.

27. I. U. Kathir, Tafsir al-quran al-azim. Riyadh: Dar toyyibah li al-nasyr wa al-tawzi', 1997.

28. Islamweb.net, Tafsir qouluhu Taala fas alu ahl al-zikr Available: https://fatwa.islamweb.net/ar/fatwa/38050/.

29. M. F. I. Al-duwali, Qarar bi sya'ni al-ifta': Syurutuhu wa adabuhu. Available: http://www.iifa-aifi.org/2203.html. 
30. I. N. al-Salmiy, Usul al-fiqh alladzi la yasa'u jahlahu. Riyadh: Dar al-tadmuriyyah, 2005.

31. S. M. Bates, "Guidance for the treatment and prevention of obstetric-associated venous thromboembolism," J Thromb Thrombolysis, 41, 2016, pp. 92-128.

32. A. Kafi, Al-hajah al-syar'iyyah hududuha wa qawaiduha. Beirut: Dar al-kutub al-ilmiyyah, 2004.

33. I. Q. Al-jawziyyah, The Prophetic Medicine English Transalation by Abd Qadeer. Dal al-Ghad al-Jadid: Mansurah, 2003.

34. A. M. Al-Shatibi, Al-muwafaqat fi usul al-shariah. Dar al-Kutub al-Ilmiyyah, 2004.

35. H. N. Suharjono, Trends of maternal deaths attributed to VTE in Sarawak 2008-2016. Slide presentation. 